\title{
Nada Vendo no Escuro, Nada Ouvindo no Silêncio
}

\author{
André Abath \\ andreabath@gmail.com \\ Universidade Federal de Minas Gerais, Belo Horizonte, MG, Brasil
}

resumo Podemos ver na ausência de luz, e ouvir na ausência de som? Em seu livro Seeing Dark Things: The Philosophy of Shadows (2008), Roy Sorensen defende que sim, que podemos ver a escuridão na ausência de luz, e ouvir o silêncio na ausência de som. Neste artigo, defendo que na escuridão nada vemos, no silêncio nada ouvimos, e que experienciar a ausência de luz e som é uma questão afetiva, e não perceptual.

palavras-chave Percepção; Escuridão; Silêncio; Ausências; Roy Sorensen

\section{Introdução}

Precisamos da luz para ver, e do som para ouvir? Uma resposta depende, é certo, do modo como caracterizamos a visão e a audição. Consideremos, por exemplo, o que diz John Heil:

Ver envolve a atividade de extrair informação a partir da radiação de luz; ouvir ocorre quando uma criatura ganha informação a partir de certos tipos de ondas de pressão; olfato e paladar envolvem a extração de informação a partir de características químicas do ambiente (o primeiro a partir de características carregadas através do meio da criatura... o segundo a partir de características físicas das coisas ingeridas); o toque incorpora a capacidade de obter informação sobre as coisas a partir de algum tipo de contato mecânico $\left(1983\right.$, p.8). ${ }^{1}$ 
Nessa passagem, Heil defende que os sentidos devem ser caracterizados em termos dos estímulos físicos próprios a cada um deles, e a partir dos quais um organismo extrai informação acerca de seu ambiente. O estímulo próprio da visão é a luz; o da audição são ondas sonoras. Se assim for, a visão depende da presença de luz, e a audição da presença de ondas sonoras. Não há visão sem luz, e audição sem som.

Essa é uma caracterização interessante. Em parte, por abrir espaço teórico para que possamos ver e ouvir a partir de órgãos que não os habituais olhos e ouvidos. É, afinal, plenamente razoável pensar que órgãos diversos possam ser utilizados para a visão e audição; que um organismo bastante distinto de nós, sem nada (ou muito pouco) que se assemelhe a um aparelho ocular e auditivo humano, possa ser considerado como possuindo tais sentidos. ${ }^{2}$

O que seria, afinal, ver sem luz, e ouvir sem som? Bem, na ausência de luz, há escuridão; na ausência de som, silêncio.Ver na ausência de luz seria ver a escuridão; ouvir na ausência de som seria ouvir o silêncio. Roy Sorensen, em seu livro Seeing Dark Things: The Philosophy of Shadows (2008), defende que não, não precisamos da luz para ver e do som para ouvir, porque vemos a escuridão e ouvimos o silêncio. Neste artigo, gostaria de discordar de Sorensen, defendendo uma posição segundo a qual na escuridão nada vemos, no silêncio nada ouvimos, e experienciar a ausência de luz e som não é uma questão perceptual, mas sim afetiva.Tal defesa não implica, diga-se de imediato, em uma refutação definitiva da posição de Sorensen. O que busco é, ao mesmo tempo, fazer jus à fenomenologia da experiência das ausências e respeitar uma caracterização da visão e audição em termos de seus estímulos físicos próprios. Se a posição apresentada aqui é vantajosa em relação à defendida por Sorensen, o é à luz de tais objetivos.

\section{Sonhos de Escuridão na Escuridão}

Sorensen, diga-se de imediato, não apresenta claros argumentos em defesa da visão do escuro e audição do silêncio. Apresenta, ao invés, uma série de cenários, e sugere que, diante deles, deveríamos abandonar a nossa inclinação natural de tomar a luz como necessária para a visão e o som 
como necessário para a audição, já que o modo adequado de descrevê-los seria em termos de visão do escuro e audição do silêncio. Gostaria de percorrer alguns desses cenários (os que suponho serem centrais). Buscarei, inicialmente, mostrar que, para cada um deles, podem ser igualmente bem descritos em termos de um nada ver no escuro, e nada ouvir no silêncio.

Em um dos cenários imaginados por Sorensen, temos um explorador de cavernas que dorme na completa escuridão, e, em seu sono, sonha estar em uma caverna completamente escura. Diz-nos Sorensen:

$\mathrm{Na}$ escuridão completa, vemos ao menos a escuridão. Fazemos a distinção entre experiências que estão ligadas (that lock onto) à escuridão e experiências ilusórias do escuro. Por exemplo, se um explorador de cavernas está em uma caverna completamente escura sonhando que está em uma caverna completamente escura, então ele não vê a escuridão da caverna - ou a escuridão de qualquer coisa. De forma a ver a escuridão da caverna, ele precisa acordar e olhar ao seu redor (2008, p.240).

Sorensen traça aqui uma analogia entre o que seria ver o escuro e a visão de objetos. Quando sonho com o Cristo Redentor, obviamente não vejo o Cristo Redentor. De forma a ver o Cristo Redentor, preciso estar de olhos abertos diante dele, e precisa ser a causa de minha experiência visual. (Poderia, afinal, estar diante dele, de olhos abertos, e, ainda assim, aluciná-lo, em cujo caso não o estaria vendo; estaria em uma situação de alucinação verídica). ${ }^{3}$ As mesmas exigências precisariam ser satisfeitas para que haja visão do escuro.

Certamente há uma distinção a ser feita entre sonhar a escuridão e estar na escuridão, de olhos abertos, com o aparelho visual funcionamento adequadamente, e sem que haja qualquer episódio de alucinação envolvido. Mas que distinção é essa? Será uma distinção entre sonhar a escuridão e vê-la? Não precisamos descrever as coisas dessa forma. Podemos estar diante de duas formas de nada ver. Quando sonhamos a escuridão, nada vemos. E isso não só quando sonhamos a escuridão: quando sonhamos, quando dormimos, nada vemos - ainda que sonhemos com paisagens deslumbrantes. E nada vemos por razões óbvias: não há uso de nosso aparelho visual; estamos de olhos fechados. Na escuridão, 
também nada vemos, apesar de nossos olhos estarem abertos, e nosso aparelho visual funcionando adequadamente. Mas, aqui, nada vemos porque, na escuridão, na ausência de luz, nada pode ser visto. Ou seja, podemos nada ver ou porque fechamos os olhos, eliminando o uso de nosso aparelho visual, ou porque, na ausência de luz, nada pode ser visto.

Seguindo essa distinção, o explorador nada vê quando sonha a escuridão da caverna, e nada vê quando acorda no escuro. Mas estamos diante de formas distintas de nada ver. Por que não seria essa uma descrição adequada para o cenário?

\section{Visão Não-Epistêmica do Escuro?}

Uma segunda analogia que Sorensen deseja estabelecer entra a visão do escuro e a visão de objetos diz respeito a uma distinção feita por Dretske (1969) entre usos epistêmicos e não epistêmicos de "ver" "Ver", em seus usos epistêmicos, implica crença por parte daquele que vê. Um exemplo de tal uso seria a seguinte frase: "Vejo que há dois filhotes de urso atrás da fêmea”. Se assim for, creio que há dois filhotes de urso atrás da fêmea. ${ }^{4}$ Como diz Dretske, “quando o verbo 'ver' tem nominal factivo (que...)... como seu complemento, a descrição do que alguém vê tem consequências epistêmicas" (2000, p.98). Já em seus usos não-epistêmicos, "ver" não implica crença; é compatível com a suspensão do juízo, com a ausência completa de crença, e mesmo com a descrença. Um exemplo seria a seguinte frase: "O gato Félix está vendo as nuvens no céu". Esse uso de "ver" é compatível com a ausência de crenças por parte de Félix acerca da presença de nuvens no céu, e mesmo com uma ausência geral de crenças.

Feita essa distinção, Sorensen apresenta-nos com um cenário, que será descrito como um no qual podemos ver o escuro ainda que na descrença de vê-lo, ou ainda que suspendamos o juízo acerca de ver ou não o escuro. O cenário envolve dois sujeitos, Sra. Atéia e Sr. Agnóstico. Ambos são sequestrados, e os marginais anunciam que os cegarão, com o uso de lasers em suas retinas. Ocorre, então, o seguinte:

Cada um dos sequestrados vê um flash de luz vermelha, e então a escuridão. Sra. Atéia infere que está cega. Na verdade, os sequestradores 
apenas apagaram a luz depois do flash vermelho. Sra. Atéia acredita que não está vendo nada, mas, na verdade, está vendo a escuridão no quarto... Um caso mais revelador é o de seu cossequestrado, Sr. Agnóstico. Ele é mais circunspecto que a Sra. Atéia. O Sr. Agnóstico nem crê nem descrê que está cego. Ele pensa que não possui evidência o suficiente para decidir a questão, e, portanto, é neutro acerca de estar ou não vendo algo (2008, p.247).

Portanto, segundo Sorensen, Sra. Atéia vê o escuro ainda que não creia vê-lo — ela crê, afinal, estar cega, e nada ver. Já o Sr. Agnóstico, mais cuidadoso, suspende o juízo: ele nem crê nem descrê estar vendo o escuro; ele pode estar cego e nada ver, ou estar vendo o escuro. Seria, assim, possível ver o escuro de maneira não-epistêmica - na descrença, na suspensão do juízo, e mesmo na ausência de crenças -, analogamente à visão não-epistêmica de Félix das nuvens no céu.

Uma vez mais, precisamos descrever as coisas dessa forma? Precisamos tomar o caso de Sra. Atéia e Sr. Agnóstico como sendo de visão nãoepistêmica do escuro? Não. Isso porque há uma descrição alternativa, igualmente compatível com o cenário. Sra. Atéia não está cega, mas apenas no escuro. Ela está errada ao crer que está cega. Mas será que ela está errada ao crer que nada vê? Não precisamos dizer que sim. Podemos estar, novamente, diante de duas formas de nada ver. Sra. Atéia nada vê; não porque esteja cega, mas porque nada pode ver no escuro. Ela está certa ao crer que nada vê; está errada, apenas, ao crer que nada vê por estar cega. Já o Sr. Agnóstico, em sua suspensão de juízo, pode estar neutro precisamente entre as duas formas de nada ver. Ele crê que nada vê, mas suspende o juízo entre nada estar vendo por estar cego e nada estar vendo por estar no escuro, e nada poder ver.

\section{A Escuridão da Caverna e a Escuridão da Adega e do Quarto}

Caso houvesse a visão do escuro, haveria um desafio filosófico pela frente. Precisaríamos responder a seguinte pergunta: o que distingue uma percepção visual do escuro de outra? Afinal, todas as percepções visuais do escuro teriam o mesmo conteúdo; em todas elas, o mesmo seria visto: 
o escuro. Seria preciso distinguir percepções visuais do escuro de outra forma. Sorensen apresenta a sua solução para o problema (considerando a escuridão na Devil's Arse, uma caverna no norte da Inglaterra):

Turistas pagam para experienciar a total escuridão da Devil's Arse.

Visitantes dessa caverna não podem experienciar essa escuridão particular ficando em casa e apagando as luzes da adega à meia noite. Embora as experiências sejam indistinguíveis, elas diferem em virtude de suas distintas origens (IBID, p.261).

Sorensen apela, aqui, para algo inegável: experienciar a escuridão em uma caverna não é como experienciar a escuridão em uma adega, ou em nosso quarto. Isso embora as percepções visuais do escuro, caso existam, sejam indistinguíveis em seu conteúdo. Sendo assim, o que distinguiria as percepções visuais do escuro, para Sorensen, seriam suas origens. A percepção visual do escuro na Devil's Arse seria causada pela ausência de luz na Devil's Arse. A percepção visual do escuro em nosso quarto é causada pela ausência de luz em nosso quarto. Daí serem percepções visuais distintas.

Não quero questionar essa solução para o problema da distinção entre percepções visuais do escuro - o problema só surge, claro, uma vez que admitamos que há visão do escuro, o que pretendo negar. Mas gostaria de questionar a explicação de Sorensen para a distinção entre experienciar o escuro em uma caverna e em uma adega, ou em nosso quarto. Que há diferenças em tais experiências é inegável. Não me parece, contudo, que as diferenças digam respeito à origem das percepções visuais. $\mathrm{O}$ que torna a experiência em uma caverna distinta da experiência em uma adega, ou em nosso quarto, diz respeito a outros sentidos que não à visão, e a nosso envolvimento emocional com o ambiente. Os odores que sinto na caverna - e há um odor particular, que deu origem a seu nome - não são os que sinto na adega, ou em meu quarto. O que toco não é o mesmo - na caverna, rochas frias, em casa, as paredes familiares. O que ouço não é o mesmo - em casa, os ruídos habituais da madrugada lá fora, na caverna, "o som arrepiante da água corrente e os ecos de uma era passada" (como descrito no anúncio da visita). A experiência de estar em uma caverna é multissensorial. Em sua multissensorialidade, é radicalmente distinta da experiência de estar em casa no escuro. Em parte em consequência dessa 
distinção radical - e em parte por aquilo que ocupa nossa mente na caverna -, o nosso envolvimento emocional com o ambiente também não será o mesmo nas duas situações. Por isso pagamos para ter tal experiência: não pela escuridão, mas por aquilo que, multissensorialmente e emocionalmente, sentiremos. Caso fôssemos seres apenas visuais, sem outros sentidos, e caso não soubéssemos estar em uma caverna com uma rica história, estar na Devil's Arse seria exatamente como estar na adega ou em nosso quarto no escuro. Seriam todos casos em que - na descrição que venho apresentando - nada estaríamos vendo, por nada podemos ver.

\section{Pode o Silêncio ser Experienciado?}

Segundo Sorensen, além de ver a escuridão, podemos ouvir o silêncio. Também aqui defenderei que não ouvimos o silêncio; no silêncio, nada ouvimos.

Antes, porém, precisamos lidar com uma óbvia objeção inicial a Sorensen. Será que, para aqueles que ouvem, há tal coisa como experienciar o silêncio, a completa ausência de som (seja essa experiência uma de ouvir o silêncio ou um nada ouvir, por não haver nada a ser ouvido)? Como salienta o próprio Sorensen (a partir de um relato do compositor John Cage), mesmo em câmaras anecóicas (sem eco), na completa ausência de som de fundo (ou ao menos na completa ausência de som de fundo que seja audível por seres humanos), ouvimos, ainda assim, sons: aqueles produzidos por nosso próprio corpo, como o da circulação sanguínea e mesmo da operação do sistema nervoso. Isso levou Cage a dizer que "não há tal coisa como o silêncio" (1961, p.8).5

Essa não é a conclusão correta a tirar-se da situação. Certamente há silêncio - no espaço vazio, por exemplo. A questão é se podemos experienciar o silêncio, uma vez que aqueles que ouvem parecem sempre, em qualquer ambiente, ouvir sons, nem que sejam os sons produzidos pelo funcionamento do próprio corpo. Mas se não há experiência do silêncio, não haveria nada como ouvir o silêncio.

Mas claro que, habitualmente, falamos em certos ambientes como silenciosos: a casa de campo é silenciosa, assim como meu quarto e a biblioteca. Isso embora, neles, não haja completa ausência de som. O que 
dizemos é, então, falso? Não necessariamente. Podemos dizer, seguindo uma posição apresentada por Dretske (1983), que o termo "silêncio" é semanticamente semelhante ao termo "vazio". Um espaço é vazio quando não há qualquer coisa nele. Mas o que conta como uma coisa pode variar de contexto para contexto. Um copo sem líquido é tipicamente considerado vazio, ainda que esteja cheio de ar. Uma sala de aula sem pessoas e móveis pode ser considerada vazia, ainda que haja lâmpadas em seu teto. $\mathrm{O}$ ar, no primeiro caso, e as lâmpadas, no segundo, não contam como coisas, em tais contextos. De maneira análoga, um ambiente é silencioso se nele não há som. Mas o que conta como som pode também variar de contexto para contexto. Uma sala de aula em prova é silenciosa quando todos estão calados, ainda que nela chegue o som produzido pelos pássaros lá fora. Um quarto é silencioso quando não recebe sons do trânsito, ainda que receba o som produzido pela brisa marinha. O som dos pássaros, e o som da brisa, é, em tais contextos, irrelevante para a descrição dos ambientes como silenciosos.

Se assim for, podemos falar em ambientes silenciosos, e da experiência desses ambientes como sendo uma do silêncio. Essa é, em linhas gerais, a saída de Sorensen para a objeção segundo a qual não há tal coisa como a experiência do silêncio. Retomarei a discussão sobre o que é experienciar a ausência de som mais a frente, na seção IX. Por hora, tomemos a posição de Sorensen como adequada, e sigamos.

\section{Ouvindo o Silêncio?}

Considere o seguinte cenário apresentado por Sorensen:

Um soldado ferido que se pergunta se ficou surdo pode ouvir o silêncio ainda que permaneça neutro sobre estar ou não ouvindo o silêncio. Ele espera estar ouvindo o silêncio, mas não crê nem descrê que está ouvindo o silêncio (2008, p.268).

Assim como no caso da visão da escuridão, a audição do silêncio poderia ser não-epistêmica: poderíamos ouvir o silêncio ainda que na ausência de crenças, na descrença, ou na suspensão do juízo, como o soldado ferido. E há outros paralelos com a idéia da visão do escuro. Sonhar o silêncio ou 
alucinar o silêncio não seria ouvir o silêncio. Para ouvir o silêncio, teríamos que estar diante da ausência de som, com o aparelho auditivo funcionando adequadamente, e essa ausência deveria ser a causa da experiência auditiva do silêncio (IBID, p.269).

Em ambos os casos, porém, paralelamente ao que dissemos acerca da suposta visão do escuro, podemos dar uma descrição distinta. O soldado ferido está em dúvida, mas sua dúvida é entre duas formas de nada ouvir: estaria ele nada ouvindo por não ser mais capaz de ouvir, ou nada ouvindo por não haver som, por não haver nada a ser ouvido? 6 Seu pensamento poderia ser expresso como: "Não consigo ouvir nada. Estou surdo, ou está tudo em silêncio?".

Já quem sonha com o silêncio não ouve nada, assim como quem está em um ambiente silencioso. Mas são formas distintas de nada ouvir. No ambiente silencioso, o aparelho auditivo está em normal funcionamento, estamos em plena consciência, mas nada há para ser ouvido. Quando imersos no sono profundo, ainda que o aparelho auditivo esteja em funcionamento, e haja som no ambiente, a informação extraída não chega à nossa consciência, e nada ouvimos (conscientemente, ao menos).

\section{0 Caso Audrey}

Um cenário mais interessante descrito por Sorensen busca mostrar que a experiência do silêncio (enquanto ouvir o silêncio) possui um aspecto qualitativo. Ele pede-nos para imaginar o caso de Audrey, uma cientista acústica que, até determinado momento de sua vida, esteve sempre em ambientes barulhentos, e nunca experienciou o silêncio. Continua Sorensen:

Audrey conhece os aspectos físicos do silêncio. Mas ela quer

experienciar o silêncio, e então constrói uma câmara à prova de som.

Quando ela entra na câmara, Audrey aprende algo: como é (what is it

like) escutar o silêncio. Ela fecha os olhos para escutar mais

atentamente. Ela aprecia o silêncio assim como outros podem apreciar

o borbulhar de um riacho... (IBID, p.271).

É certo que há um aspecto qualitativo envolvido em estar, com nosso aparelho auditivo em funcionamento adequado, em ambientes silenciosos. 
Em parte por isso, aqueles que vivem na cidade fogem para o interior, para o campo. E certamente podemos dizer que, em tais casos, há uma experiência do silêncio. Mas o que é experienciar o silêncio? É ouvi-lo?

Quando Audrey entra na câmara à prova de som, o que ela aprende, passa a conhecer, afinal? Os aspectos qualitativos envolvidos em escutar o silêncio? Não precisamos descrever as coisas dessa forma. Podemos dizer o seguinte: o que ela aprende, o que passa a conhecer, são os aspectos qualitativos envolvidos em nada ouvir com o aparelho auditivo funcionando adequadamente, e em plena consciência; ela passa a conhecer os aspectos qualitativos envolvidos nessa forma específica de nada ouvir, distinta da forma de nada ouvir presente no sono, por exemplo.

Quando ela fecha os olhos, não é para escutar mais atentamente o silêncio. Posso focar minha atenção em um estímulo sonoro em detrimento de outro: no som dos pássaros ao invés do pinga-pinga da pia que vaza na cozinha. Mas na ausência de estímulos sonoros, não há exercício auditivo da atenção. Quando Audrey fecha os olhos, no silêncio, não há nada para ser escutado. Ela fecha os olhos de forma a voltar a sua atenção para dentro (se podemos falar assim): para sua experiência naquele instante. Ou seja, ela deseja voltar sua atenção para o aspecto qualitativo da experiência do silêncio. O que não significa que ela esteja ouvindo o silêncio. Pode significar que ela nada ouve, e aprecia a experiência, o aspecto qualitativo, dessa forma de nada ouvir.

Sorensen concorda que, na surdez, ou com os ouvidos tampados, nada ouvimos. De forma a ouvirmos o silêncio, precisaríamos estar de ouvidos abertos, com o aparelho auditivo em pleno funcionamento, em um ambiente silencioso. Mas, se assim fosse, não seria de se esperar que a experiência do nada ouvir (seu aspecto qualitativo), na surdez ou com os ouvidos tampados, fosse bastante distinta da experiência da audição do silêncio? Porém, a descrição da experiência dos sujeitos em câmaras anecóicas é próxima da que temos com os ouvidos tampados. Em seu conteúdo, não é uma experiência de silêncio completo; ouvimos com intensidade o funcionamento de nosso próprio organismo. Qualitativamente, não é uma experiência prazerosa, mas sim perturbadora. ${ }^{7}$ Se assim for, Audrey poderia ter tido uma experiência do silêncio (ainda que incompleto) sem construir ou buscar uma câmara à prova de som: poderia ter simplesmente tampado os ouvidos. 


\section{A Experiência da Ausência}

Se Sorensen estivesse certo, veríamos diretamente - não-epistemicamente - a escuridão, e ouviríamos o silêncio. Teríamos uma percepção direta de ausências: ausência de luz e som. Em minha interpretação alternativa dos cenários apresentados até o momento, não percebemos diretamente a ausência de luz e som. Afinal, não vemos a escuridão e ouvimos o silêncio; na escuridão e no silêncio, nada vemos, e nada ouvimos. Venho, porém, admitindo que há tal coisa como a experiência do silêncio, e admito que também há a experiência da escuridão. Quero admitir que há tal coisa como ter a experiência da ausência de som e luz. Contudo, não compreenderemos tal experiência simplesmente afirmando que nela, nada vemos e nada ouvimos, e que há um aspecto qualitativo vinculado ao nada ver e ouvir. Parando aqui, não faremos jus à nossa fenomenologia; afinal, a ausência de som e luz parecem ser experienciadas em sentido robusto; parecem figurar em nossa experiência. Mas como seria isso possível, se a ausência não é vista ou ouvida?

Sorensen cita Sartre como um daqueles que defendem que a experiência da ausência é fenomenologicamente explicada (ou, se for preferido, descrita) em termos de expectativas perceptualmente frustradas. No famoso exemplo dado em O Ser e o Nada (1943:43-5), Sartre tem um encontro marcado com seu pontual amigo Pierre, em um café. Porém, quando chega, com 15 minutos de atraso, nota que Pierre não está. Ele experiencia, então, a ausência de Pierre, com intensidade tamanha a ponto de o café, e seus ocupantes, tornarem-se periféricos na experiência, ocupada em seu centro pela própria ausência. Diz Sartre: "Mas, precisamente, eu esperava ver Pierre, e minha espera fez chegar à ausência de Pierre com um evento real acerca desse café...” (1943, p.45).

Sartre tinha uma expectativa: de que Pierre estivesse no café quando chegasse. Quando percorre o café com o olhar, não encontrando Pierre entre os diversos clientes, Sartre tem sua expectativa frustrada. $\mathrm{O}$ mundo diante de si é revelado com distinto do esperado. O que ele experiencia, então, é uma inconformidade entre sua expectativa da presença de Pierre e sua percepção do café, de seus ocupantes, que lhe revela a ausência do amigo. A experiência de Pierre como ausente é precisamente a experiência dessa inconformidade. ${ }^{8}$ 
Robert Solomon (2001, p.266) toma o exemplo de Sartre como sendo um que nossa experiência da ausência é perceptual. No café, diz ele, "não vejo apenas mesas, cadeiras, copos e outras pessoas (mas não Pierre). Também vejo a ausência de Pierre". 9 Mas devemos dizer que vemos a ausência de Pierre ou que a experienciamos não-perceptualmente? Fenomenologicamente, a segunda descrição é a mais adequada. O que nós vemos é o café, os objetos e as pessoas que o ocupam, além de propriedades diversas. Mas não vemos Pierre, nem como ausente - sua ausência é apenas relevada perceptualmente. ${ }^{10}$ Caso estivéssemos na posição de Sartre, e ligássemos para Pierre, em seguida, poderíamos legitimamente dizer algo como "senti sua falta no café". O uso do verbo "sentir", aqui, diz muito acerca da fenomenologia da experiência. A experiência da inconformidade entre uma expectativa e uma percepção envolve uma resposta afetiva; ela é sentida, e não uma percepção de ausências.

Assim interpretado, de forma não-perceptual, o exemplo de Sartre é de grande ajuda para compreendermos a experiência de ausências. Porém, pouco antes de apresentá-lo, Sartre diz ser "evidente que o nãoser aparece sempre nos limites de uma espera humana" (1943, p.41). Nesse ponto, discordamos. Porque há casos em que experienciamos a ausência (o "não-ser") na ausência de uma expectativa de presença. Suponha, por exemplo, que visito a casa de minha infância, agora vazia, e posta à venda. Ao fazê-lo, experiencio os móveis, o meu cachorro, os meus pais, como ausentes na casa - sinto-os todos como ausentes, como faltando no ambiente. Mas eu não esperava que eles estivessem presentes. Tinha plena consciência de que a casa estaria vazia. Como, então, compreender essa experiência de ausência?

$\mathrm{Na}$ sequência de sua discussão sobre o exemplo de Sartre, Solomon diz que "o nada [entendido como ausência] sempre requer uma atividade de nossa parte, uma expectativa, um desejo, uma imaginação" (2001, p.267). De fato. Nem sempre uma expectativa estará na origem de uma experiência de ausência, mas há de haver algum estado mental anterior na origem de tal experiência - um estado que pode ou não ser satisfeito, a depender do modo como o mundo se revela. No caso acima, ao entrar em minha casa, agora vazia, relembro cenas de minha infância, da casa tal como era no passado. Ao fazê-lo, desejo que a casa estivesse ainda como 
durante aqueles anos, habitada por meus pais, meu cachorro, com todos os seus antigos móveis.

Mas minha percepção da casa vazia frustra meu desejo; ou seja, o desejo não é satisfeito pelo mundo tal como me é revelado. Experiencio, assim, a inconformidade entre meu desejo e o mundo. Essa experiência é a da ausência de meus pais, meu cachorro, dos móveis, naquele ambiente. Diante dessa experiência, poderia dizer a mim mesmo: "Queria que estivessem aqui. Sinto sua ausência na casa".

Assim como no exemplo de Sartre, não há razões para supormos que a experiência da ausência é, aqui, perceptual. Eu não vejo meus pais, meu cachorro, os móveis, como ausentes. Eu sinto sua ausência, a partir da experiência de inconformidade descrita.

\section{A Experiência da Ausência de Luz}

Há, portanto, casos em que experienciamos a ausência sem percebê-la. Podemos também experienciar a ausência de luz e som sem vê-la e ouvila? Parece-me que sim, e que tais experiências são análogas às que acabamos de considerar.

Consideremos alguns cenários. Suponha que me encaminho para minha sala de aula, à noite, e que espero que ela esteja, como sempre esteve em minha chegada, iluminada. Ao chegar, encontro a sala às escuras. Tateando as paredes, encontro o interruptor de energia; porém, mesmo quando acionado, a escuridão permanece.

Ou suponha que sou um policial federal, envolvido na investigação de uma sequência de homicídios bárbaros. Tenho alguma evidência - embora não decisiva - de que o assassino encontra-se em determinada residência. Para lá sigo, e, sem autorização, invado a casa pela janela. Todo o ambiente interno está às escuras. Ouço vozes e gritos. Tateio as paredes, procurando navegar pelos cômodos, e buscando localizar o - agora provável - assassino.

Em ambos os casos, experiencio a ausência de luz. No primeiro caso, tenho uma expectativa frustrada: de que a sala esteja iluminada. Experiencio, assim como no exemplo de Sartre, uma inconformidade entre minha expectativa e o modo como o ambiente se revela. No segundo, meus 


\section{4}

movimentos pouco seguros, no escuro, tateando as paredes, possuem um objetivo: encontrar o assassino. Mas a presença de luz é, de meu ponto de vista, uma condição necessária - ou, no mínimo, extremamente desejável - para que o objetivo seja alcançado. Desejo, portanto, profundamente, que haja luz; minha sobrevivência pode depender disso. Uma vez que a ausência de luz persiste, meu desejo é frustrado. Experiencio, então, uma inconformidade entre meu desejo e o modo como o mundo se revela - além, claro, do imenso temor de ter minha vida em risco. ${ }^{11}$

Em ambos os casos, eu experiencio a luz como ausente. Há um aspecto qualitativo envolvido: sinto a ausência da luz, com base na inconformidade entre expectativa, desejo, e o modo como o mundo se revela. Mas assim como posso experienciar a ausência de um amigo em um café, ou de meus pais na casa da minha infầncia, sem vê-la, posso experienciar a escuridão sem vê-la. Ela é sentida. Na escuridão, eu nada vejo.

Há, contudo, uma dificuldade adicional aqui. No exemplo de Sartre, eu vejo algo: o café, seus clientes, objetos diversos etc. Aquilo que eu vejo releva-me que Pierre está ausente, ainda que a própria ausência não seja vista. O que dizer, porém, a esse respeito, nos casos envolvendo a experiência da escuridão? Eu quero dizer que a escuridão é experienciada, sentida, mas não vista. Mas como me é revelado que está escuro? Não seria pela própria visão? Mas se é a própria visão que me revela estar escuro, eu não estaria vendo o escuro? O problema é bem posto por David Lewis:

...na escuridão profunda, descobrimos pela visão que está escuro. De que outra forma - pelo cheiro? Pelo próprio fato de não vemos? Não, porque também não vemos na luz ofuscante ou na neblina espessa, e é pela visão que distinguimos várias situações em que não vemos $\left(1980\right.$, p.246). ${ }^{12}$

Lewis supõe que há formas distintas de nada ver - como também eu tenho suposto, com base em outros casos. E, em certos contextos, é certamente legítimo dizer que nada vemos na luz ofuscante e na neblina espessa - afinal, não podemos ver objetos. Quando, dirigindo na neblina, dizemos “eu não vejo nada!”, buscamos comunicar que não vemos qualquer objeto - assim como o professor que diz, em sala de aula, estar feliz por não estar ouvindo nada durante a prova, busca comunicar estar feliz 
com a ausência de sons vocalmente produzidos pelos alunos. E o que há em comum em casos de escuridão, neblina e luz ofuscante é que, em todos eles, objetos não são vistos. Mas não precisamos supor que vemos a escuridão para distingui-los. Na neblina e na luz ofuscante há, obviamente, luz. A luz permite-nos ver algo, embora não objetos. Na neblina espessa, podemos ver, por exemplo, os distintos tons de cinza nela presentes. Podemos mesmo sair ao redor do mundo buscando fotografar paisagens sob neblina espessa. Haverá (ou pode haver) diferenças entre elas - em tons de cor, por exemplo - e tais diferenças são visualmente acessíveis. O que significa que, afinal, algo é visto. $\mathrm{O}$ mesmo ocorre na luz ofuscante. Ela pode impedir que vejamos objetos, mas podemos buscar produzir imagens diversas de luz ofuscante, com diferentes combinações de cores; tais imagens serão distintas, e serão distintas de uma forma visualmente acessível; podem até mesmo ter grande interesse estético.

Nada disso ocorre em casos de escuridão. Todas as imagens da escuridão são, necessariamente, enquanto imagens de escuridão, iguais. Produzir imagens dos diversos tons de cor que compõem a neblina, ou das combinações de cores na luz ofuscante, é um projeto; produzir imagens da escuridão completa não é.Todas tais imagens, e todos os casos em que estamos na escuridão, são casos em que, de fato, nada vemos. $\mathrm{Na}$ neblina, na luz ofuscante, algo é visto, embora não objetos.

Como, então, descobrir que estamos na escuridão? Não vendo a escuridão, mas nada vendo na escuridão, com os olhos abertos, e com nosso aparelho visual em funcionamento adequado. E distinguimos tais casos dos de neblina e da luz ofuscante porque, nesses, algo é visto. Muito embora, em contextos diversos, seja legítimo dizer que, tanto na escuridão, na neblina, quanto na luz ofuscante, nada vemos; o que revela algo acerca da sensibilidade contextual de "nada ver", mas apenas isso.

\section{A Experiência da Ausência de Som}

Nas execuções da obra 4'33", de John Cage, um pianista chega a seu instrumento ${ }^{13}$, senta-se, abre uma partitura, posiciona-se para tocá-lo, mas, ao invés de fazê-lo, fecha sua tampa, e, observando um relógio, simplesmente aguarda a passagem do intervalo de tempo descrito no título da 
obra. A plateia supõe estar diante de quatro minutos e trinta e três segundos de silêncio. Para John Cage, porém, "não há tal coisa como o silêncio. O que eles [na plateia] achavam ser o silêncio, porque não sabiam como ouvir, era cheio de sons incidentais. Você podia ouvir o vento movendose lá fora no primeiro movimento..." (CAGE apud SORENSEN, 2008, p.65). Ou seja, a intenção de Cage ao conceber a obra não era promover uma experiência de silêncio, mas promover um voltar a atenção da plateia para a riqueza e diversidade sonora do próprio ambiente.

Cage está certo em achar que durante as execuções de sua obra não há silêncio absoluto. E não há dúvida que, caso a plateia conheça a obra de antemão, e as intenções de Cage ao concebê-la, estará voltada para tais sons incidentais, e o ambiente não poderá ser descrito como silencioso ao menos não de uma forma que envolva experiência do silêncio. Mas imaginemos uma plateia que desconhece a obra e as intenções do seu autor ao concebê-la. E consideremos a experiência de um dos indivíduos na plateia.

Ao entrar na sala de concertos, ele de fato esperava que, ao sentar-se em seu instrumento, o músico executaria uma obra ao piano pelo intervalo de tempo descrito em seu título. Quando isso não ocorre, ele experiencia algo, a frustração de sua expectativa; ou, em outros termos, experiencia a inconformidade entre a expectativa de um certo som oriundo do piano e sua ausência.

Uma experiência semelhante ocorre quando, durante uma sessão de cinema, um personagem central abre a boca para dizer suas primeiras palavras, porém nenhum som chega aos nossos ouvidos: houve uma pane no sistema sonoro da sala de cinema. O que experienciamos é uma frustração, a frustração da expectativa de um certo som oriundo do personagem ${ }^{14}$; ou, nos termos que venho utilizando, experienciamos a inconformidade entre uma expectativa de som e sua ausência.

Ainda que não haja, em tais situações, silêncio absoluto, há tal coisa como uma experiência do silêncio. Esperamos que haja um certo som oriundo de certas partes do mundo. Quando o som não chega a nós, há uma frustração de expectativa, ou seja, a experiência de inconformidade. Tal é a experiência do silêncio.

Podemos, também, imaginar casos em que a experiência do silêncio tenha sua origem não na frustração de uma expectativa, mas sim de um 
desejo de que haja um certo som oriundo de uma parte do mundo. Um pai que, após uma violenta briga com um filho, não ouve a sua voz por meses, não espera, mas deseja ouvi-lo. Isso não ocorrendo, tem seu desejo frustrado, e uma experiência de silêncio, o silêncio do filho.

Note-se que, para falar na experiência do silêncio, não precisamos dizer que nada, absolutamente nada, está sendo ouvido. Na sala de concerto e no cinema, sons do ambiente são ouvidos. O pai ouve sons na casa em que mora com o filho. Mas aquilo que era esperado ou desejado não está sendo ouvido. Quando, em tais situações, dizemos "não estou ouvindo nada”, queremos dizer precisamente isso: esperávamos ou desejávamos ouvir um certo som oriundo daquele ponto do mundo, e nada ouvimos daquilo que esperamos ou desejamos que seja de lá oriundo. Ou seja, experienciar o silêncio, em tais casos, não é ouvi-lo: é sentir o silêncio, nada ouvindo, daquilo que esperamos ou desejamos ouvir, em um ponto do mundo.

\section{Buscando a Escuridão e o Silêncio}

Até o momento, buscamos compreender a experiência das ausências, e particularmente da ausência de luz e som, em termos de uma experiência de inconformidade entre certos estados mentais - como expectativas e desejos - e o mundo. Há, porém, casos mais complicados, que não podem ser abarcados por essa descrição.

Quando apago as luzes de meu quarto à noite, não espero ou desejo iluminação. Espero e desejo a ausência de luz. Não há qualquer inconformidade entre minhas e expectativas, desejos, e o mundo. Ainda assim, parece haver, também aqui, algo como uma experiência de ausência da luz.

Já quando saio da cidade rumo ao campo, não espero ou desejo ruído. Espero e desejo a ausência dele. Se, chegando ao campo, encontro essa ausência, não há qualquer inconformidade entre expectativas, desejo e o mundo. Porém, não teria eu, nessa situação, uma experiência que poderia ser legitimamente descrita como sendo do silêncio?

Há uma resposta afetiva vinculada à ciência da inconformidade entre uma expectativa, um desejo e o mundo. Mas há também uma resposta afetiva vinculada à ciência da satisfação de uma expectativa ou desejo por 
parte do mundo. Se tenho um profundo desejo por certa cerveja belga, quando enfim chego a bebê-la, sinto não apenas o prazer desencadeado por sua degustação, mas o prazer de ter meu desejo satisfeito - que pode ser mesmo anterior à própria degustação, surgindo quando tenho a cerveja diante de mim.

De maneira similar, quando, cansado após um longo dia sob o sol, desejo a escuridão de meu quarto, o apagar das luzes traz uma experiência prazerosa, que é, ao menos em parte, a da satisfação de meu desejo de escuridão. Ou se, após meses no ruído da cidade, desejo a ausência desse ruído, a chegada ao campo traz também uma experiência prazerosa que é, ao menos em parte, a da satisfação de meu desejo de silêncio (ou de menos ruído).

A experiência da ausência de luz e som, portanto, não precisa ser de inconformidade entre mente e mundo. Pode ser a prazerosa experiência de conformidade, de satisfação de expectativas e desejos por parte do mundo.

No primeiro caso, de inconformidade, vimos que a experiência da ausência é mais bem compreendida como afetiva, e não como perceptual; ela é sentida, e não vista ou ouvida. O mesmo ocorre no segundo caso, de conformidade. Quando desejo a escuridão e o silêncio, e apago as luzes e fecho as janelas, ou fujo para o campo, o que busco não é ver a ausência de luz e ouvir a ausência de som, mas sim a prazerosa experiência de ter meu desejo satisfeito, nada vendo, e nada ouvindo. ${ }^{15}$

1 Todas as traduções neste artigo são de minha responsabilidade.

2 Para discussão sobre o problema da caracterização e demarcação dos sentidos, ver Grice (1962) e Macpherson (2011).

${ }^{3}$ Para discussão sobre alucinações verídicas, ver Lewis (1980).

${ }^{4}$ Isso embora possa, claro, revisar a minha crença rapidamente; por exemplo, ao mudar de posição, e notar que, o que achava ser um outro filhote de urso, era, na verdade, um brinquedo lançado por uma criança no zoológico.

${ }^{5}$ Para Cage, essa descoberta era bem-vinda.Voltando a nossa atenção para os sons não-intencionalmente produzidos por nós, voltamo-nos para "o mundo da natureza, onde, gradualmente e subitamente, vê-se que a humanidade e a natureza, não separadas, estão nesse mundo juntas; que nada foi perdido quando tudo foi entregue. Na verdade, tudo é ganho" (1961, p.8). O otimismo de Cage em relação à ausência do silêncio contrasta com o pessimismo do histo- 
riador Thomas Carlyle, que, em carta, disse proclamar "o valor indispensável do silêncio" (CARLYLE apud PROCHNIK, 2010, p.178); buscando-o, Carlyle mandou construir um quarto supostamente à prova de som em sua casa londrina; o resultado, porém, foi desapontador: "o vento entrava por frestas no teto, onde uivava através dos defletores" (CARLYLE 1883, p.238).

6 Saliente-se que "nada a ser ouvido", aqui, deveria levar em conta os aspectos contextuais discutidos acima. O soldado poderia ouvir o som da brisa, mas não ouvir vozes, tiros, ou qualquer dos sons que esperaria ouvir em uma situação de guerra. Uma complicação do cenário, porém, não discutida por Sorensen, é que, para estar na dúvida descrita, o soldado precisaria nada ouvir como nada ouviria na surdez. "Nada", aqui, portanto, teria de referir a uma ausência completa de som. Isso torna o cenário imaginado por Sorensen implausível. Caso o soldado de fato nada ouvisse, teria fortíssima evidência de estar surdo, ao menos temporariamente.

7 Segundo o livro Guinness World of Records, o lugar mais silencioso do mundo é a câmara anecóica dos Laboratórios Orfield, em South Minneapolis. Diz-se que ninguém suportou estar dentro dela por mais de 45 minutos. Em seu livro Zero Decibels: The Quest for Absolute Silence (2010), George Foy escreve: "Mas o silêncio, ou o quanto de silêncio possa haver nesse planeta, não é assustador apenas no mundo normal, em que consistente em sua maior parte em uma ausência de fala, ausência de TV. Algumas pessoas que passaram um tempo em câmaras menos extremas que a de Orfield relataram sentir pânico, desorientação e náusea; os dois últimos sendo mais uma indicação da próxima relação entre equilíbrio e audição" (p.143).

${ }^{8}$ Experienciar a inconformidade entre uma expectativa e aquilo que é perceptualmente revelado requer ciência da inconformidade. Afinal, ainda que Pierre não estivesse no café, caso eu não estivesse ciente de que isso me é revelado perceptualmente, não haveria espaço para qualquer experiência de inconformidade. Mas tal ciência não deve ser tomada como exigindo crenças ou julgamentos explícitos. Segundo o próprio Sartre, a experiência da ausência é "pré-judicativa”, e o julgamento sua "expressão facultativa” (1943:41). Pode-se experienciar a ausência de Pierre sem julgar ou crer (explicitamente, ao menos, com expressão em linguagem natural) que Pierre está ausente. Se assim for, animais não-humanos poderiam experienciar tal ausência (embora não seja claro que Sartre gostaria de dar esse último passo). Para discordância, ver Davidson (1982).

9 Saliente-se que Sartre não diz que vemos a ausência, mas que temos "uma intuição da ausência de Pierre" (1943, p.43). Porém, "intuição", aqui, parece estar sendo usando de forma kantiana, como se referindo a uma relação perceptual pré-judicativa com algo. Nesse caso, não seria irrazoável ler Sartre como dizendo que vemos a ausência de Pierre, de forma pré-judicativa.

10 Uma elocução como "Vejo que Pierre não está aqui" seria adequada, mas o "ver que..." corresponde à crença de que Pierre está ausente; não significa que a ausência de Pierre é vista.

11 Pode, certamente, ser dito que, no primeiro caso, além da expectativa de que haja luz na sala, também desejo que isso ocorra - embora sem a intensidade do segundo caso. O que apenas significa que a inconformidade pode dar-se entre mais de um estado mental e o mundo.

doispontos, Curitiba, São Carlos, vol. 9, n. 2, p.11-31, outubro, 2012 
12 Saliente-se, porém, que Lewis não deseja defender, irrestritamente, a visão do escuro, mas sim que nosso conceito de ver é ambíguo: em certos contextos, ele é caracterizado de forma tal que há visão do escuro; em outros, de forma tal que, no escuro, nada vemos.

$13 \mathrm{Na}$ verdade, John Cage concebeu a obra como podendo ser executada por qualquer instrumento ou conjunto de instrumentos. Mas fiquemos com uma execução ao piano.

$14 \mathrm{Ou}$ da tela, ou de um ponto qualquer da sala, desde que esteja sincronizado de forma tal que pareça ser oriundo do personagem.

15 "Nada ouvindo" precisa, claro, ser tomado de acordo com os aspectos contextuais descritos acima.

\section{Referências bibliográficas}

CAGE, J. 1961. Silence: Lectures and Writings. Middletown: Wesleyan University Press.

CARLYLE, J.W. 1883. Letters and Memorials of Jane Welsh Carlyle: Volume II. Editado por FROUDE, J.A. London: Longmans, Green and Co., 1883.

DAVIDSON, D. 1982. Rational Animals. Dialectica, v. 35, n. 4, pp. 317-38.

DRETSKE, F. 1969. Seeing and Knowing. Chicago: University of Chicago Press.

. 1981. The Pragmatic Dimension of Knowledge.

Philosophical Studies, v. 40, n. 3, pp. 363-378.

2000. Simple Seeing. In: DRETSKE, F. Perception,

Knowledge and Belief. Cambridge: Cambridge University Press.

FOY, G.M. Zero. 2010. Decibels: The Quest for Absolute Silence. New

York: Scribner.

GRICE, H.P. 1962. Some Remarks about the Senses. In: BUTLER, R.J. (Ed.). Analytical Philosophy, First Series. Oxford: Oxford University Press.

HEIL, J. 1983. Perception and Cognition. Berkeley: University of California Press. 
LEWIS, D. 1980. Veridical Hallucination and Prosthetic Vision. Australasian Journal of Philosophy, v. 58, n. 3, pp. 239-249.

MACPHERSON, F. 2011. Individuating the Senses. In:

MACPHERSON, F. (Ed.). The Senses: Classical and Contemporary Readings. Oxford: Oxford University Press.

PROCHNIK, G. 2010. Pursuit of Silence: Listening for Meaning in a World of Noise. New York: Doubleday.

SARTRE, J.P.1943. L'Être et le Néant: Essai d'Ontologie

Phénoménologique. Paris: Gallimard.

SOLOMON, R.C. 2001. From Rationalism to Existentialism: The

Existentialists and Their Nineteenth-century Backgrounds. Lanham:

Rowman and Littlefield.

SORENSEN, R. 2008. Seeing Dark Things: The Philosophy of Shadows.

Oxford: Oxford University Press. 